\title{
Predictive Modelling of COVID-19 New Cases in Algeria using An Extreme Learning Machines (ELM)
}

\author{
${ }^{1}$ Messaoud DJEDDOU \\ ${ }^{2}$ Ibrahim A. HAMEED \\ ${ }^{3}$ Abolfazl NEJATIAN \\ ${ }^{4}$ Imed LOUKAM
}

\begin{abstract}
${ }^{1}$ LARHYSS Laboratory, Faculty of Sciences and Technology, Mohamed Khider University, PO box 145 RP, 07000 Biskra, Algeria.

Email: djeddou.messaoud@gmail.com
\end{abstract}

${ }^{2}$ Department of ICT and Natural Sciences, Faculty of Information Technology and Electrical Engineering, Norwegian University of Science and Technology (NTNU), Postboks 1517, 6025 Ålesund, Norway

e-mail: ibib@ntnu.no

${ }^{3}$ Department of Electrical Engineering, Florida Polytechnic University, FL, USA

Email: anejatian8607@floridapoly.edu

${ }^{4}$ INFRARES Laboratory Mohamed-Cherif Messaadia University-, Souk Ahras 41000, Algeria

Email: i loukam@hotmail.com

\begin{abstract}
In this research, an extreme learning machine (ELM) is proposed to predict the new COVID19 cases in Algeria. In the present study, public health database from Algeria health ministry has been used to train and test the ELM models.
\end{abstract}

The input parameters for the predictive models include Cumulative Confirmed COVID-19 Cases (CCCC), Calculated COVID-19 New Cases (CCNC), and Index Day (ID).

The predictive accuracy of the seven models has been assessed via several statistical parameters. The results showed that the proposed ELM model achieved an adequate level of prediction accuracy with smallest errors $(M S E=0.16, R M S E=0.4114$, and MAE $=0.2912)$, and highest performance's (NSE = 0.9999, IO $\left.=0.9988, R^{2}=0.9999\right)$. Hence, the ELM model could be utilized as a reliable and accurate modeling approach for predicting the new COVIS-19 cases in Algeria. 
medRxiv preprint doi: https://doi.org/10.1101/2020.09.28.20203299; this version posted September 29, 2020. The copyright holder for this preprint (which was not certified by peer review) is the author/funder, who has granted medRxiv a license to display the preprint in It is made available under a CC-BY-NC-ND 4.0 International license .

The proposed ELM model, it can be used as a decision support tool to manage public health medical efforts and facilities against the COVID-19 pandemic crisis.

Keywords: COVID-19, Extreme learning Machine, Modelling, Coronavirus, Algeria

\section{INTRODUCTION}

Bacteria, parasites, and viruses can cause serious diseases for human health. Still, pathogenic viruses usually cause the most serious diseases and among these viruses; coronavirus is the large family of pathogenic viruses.

Infection with these types of viruses can cause respiratory, liver, gastrointestinal and neurological diseases. They are distributed among humans, birds, cattle, mice, bats and other wildlife [1-2].

World Health Organization (WHO) received notifications from Chinese authorities about many respiratory problems was linked to people who visited a local market for seafood and wildlife in Wuhan city, Hubei Province, China [3]. Virological investigation suggests that the causative agent of this pneumonia is a new coronavirus (COVID-19) [4].

This new coronavirus has made hundreds of thousands of victims around the world and becomes a global pandemic threatening human health.

Dehesh et al. [5] proposed an ARIMA model to predict the trend of confirmed cases in different countries.. They suggest that China and Thailand had almost a stable trend. The trend of South Korea was decreasing and will become stable. Iran and Italy had unstable trends. Al-qaness et al. [6] proposed an improved adaptive neuro-fuzzy inference system (ANFIS) to forecast the COVID-19 confirmed cases ten days ahead with good performances. The model was tested using two different datasets of weekly influenza confirmed cases in USA and China.

Jung et al. [7] used a statistical estimation of the confirmed case fatality risk (cCFR) and the basic reproduction number, The estimated values of the cCFR were 5.3\% for Scenario 1 and $8.4 \%$ for Scenario 2. The basic reproduction number was estimated to be 2.1 and 3.2 for Scenarios 1 and 2, respectively. They argued that the current COVID-19 epidemic has a substantial potential for causing a pandemic. 
medRxiv preprint doi: https://doi.org/10.1101/2020.09.28.20203299; this version posted September 29, 2020. The copyright holder for this preprint (which was not certified by peer review) is the author/funder, who has granted medRxiv a license to display the preprint in

It is made available under a CC-BY-NC-ND 4.0 International license .

Zhao et al. [8] proposed a mathematical model to estimate the real number of COVID-19 cases in the first half of January 2020. They estimated that after 17 January 2020, the cases had increased 21-fold. Nishiura et al. [9] proposed an estimation model for the infection rate of COVID-19 in Wuhan, China. They conclude that the estimated rate is 9.2\%; and the death rate is $0.3 \%$ to $0.6 \%$.

Tang et al. [10] proposed a mathematical model to estimate the transmission risk of COVID19. They concluded that the basic reproduction number might be as high as 6.47 . They also predicted the number of confirmed cases in seven days (23 to 29 January 2020).

At last, In [11], data of 47 patients were used to estimate sustained human-to-human transmission of COVID-19. The author concluded that the transmission is 0.41 . However, with intense surveillance, the probability that an imported case will result in sustained transmission is only 0.012 .

Since Huang el al [12] proposed the extreme learning machine (ELM), several researches based on the application of these models in various fields of science and engineering have been published to prove their significant progress over conventional neural network models.

No iterative process is required to adjust the biases and weights of the free connections between the hidden layer and the output layer, since this adjustment is adopted randomly, thus allowing a reduction in computation time. Therefore, an ELM model is remarkably efficient particularly over conventional artificial neural network to reach a global optimum, following a universal approximation of the capacity of a single-layer feed-forward network [13-14]. More other applications of the ELM model can be found in [14].

In the present research paper, the implementation of the machine learning regression model, namely extreme learning machine (ELM) is developed for the first time to predict new COVID19 cases in Algeria.

\section{MATERIALS AND METHODS}

\subsection{Study area}

The pandemic Covid-19 in Algeria spreads from February 25, 2020. A foreign worker from Italy was tested positive for SARS-CoV-2, and then an outbreak of contagion is formed in Blida Province [15]. Sixteen members of the same family were infected with the coronavirus at a 
medRxiv preprint doi: https://doi.org/10.1101/2020.09.28.20203299; this version posted September 29, 2020. The copyright holder for this preprint (which was not certified by peer review) is the author/funder, who has granted medRxiv a license to display the preprint in It is made available under a CC-BY-NC-ND 4.0 International license.

wedding party [16]. Blida Province becomes the epicenter of the coronavirus epidemic in Algeria [17].

On April 25 2020, there were 419 deaths and 3256 COVID-19 confirmed cases in Algeria.

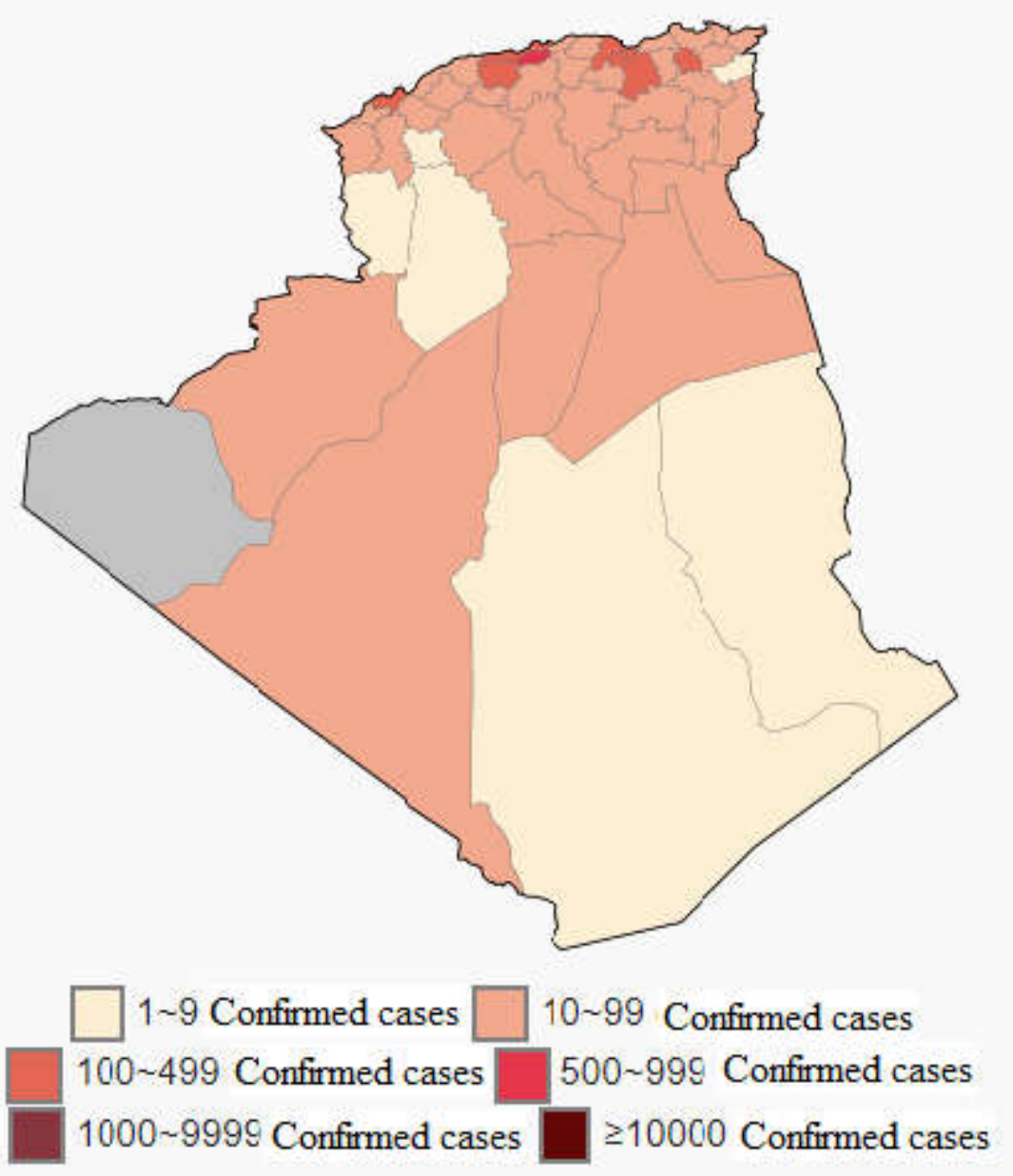

Figure 1: Map of the Covid-19 pandemic in Algeria [18]

The data used in this study include total confirmed COVID-19 cases, calculated new COVID cases, and Day index. The statistical parameters of the data used for modeling are given in Table 1 . 
medRxiv preprint doi: https://doi.org/10.1101/2020.09.28.20203299; this version posted September 29, 2020. The copyright holder for this preprint (which was not certified by peer review) is the author/funder, who has granted medRxiv a license to display the preprint in

It is made available under a CC-BY-NC-ND 4.0 International license .

Table 1 Descriptive statistics for the parameters used for New COVID-19 cases modelling

\begin{tabular}{|c|c|c|c|c|}
\hline Parameters & \multirow[t]{2}{*}{ Min. } & \multirow[t]{2}{*}{ Max. } & \multirow[t]{2}{*}{ Mean } & \multirow[t]{2}{*}{ Std. dev. } \\
\hline Inputs & & & & \\
\hline $\begin{array}{l}\text { 1- } \text { Cumulative Confirmed } \\
\text { COVID-19 Cases } \\
\text { (CCCC) }\end{array}$ & 3 & 3256 & 998.78 & 1063.67 \\
\hline $\begin{array}{ll}2- & \text { Calculated COVID-19 } \\
& \text { New Cases (CCNC) }\end{array}$ & 0 & 185 & 57.82 & 49.56 \\
\hline 3- Index Day (ID) & 1 & 7 & 4 & 2.01 \\
\hline Output & & & & \\
\hline $\begin{array}{c}\text { COVID-19 New Cases } \\
\text { (CNC) }\end{array}$ & 0 & 185 & 57.82 & 49.56 \\
\hline
\end{tabular}

\subsection{Extreme learning machines}

The Extreme Learning Machine (ELM) proposed by Huang et al. [12] is a model based on a single hidden layer neural network, which after setting the weights and biases of the hidden layer, and based on a single layer feed forward network (SLFN) algorithm, allows to obtain a closed form solution for the output weights by a least squares solution. It is drawn from a continuous probability distribution function [13].

The advantages of the ELM model are [11-13]:

1- Less complex design;

2- High classification accuracy;

3- Good generalization ability;

4- Less computing time.

During training process, the weights and biases of the hidden single hidden layer feed-forward networks (SLFN) are randomly adopted and never updated. The output weights are stated using the generalized Moore-Penrose generalized inverse of the hidden layer output matrix [19].

For a set of d-dimensional vectors defined for i $i=1,2, \ldots, N$ training samples, the SLFN with L hidden neurons is mathematically expressed as follows [12]:

$$
f_{L}(\mathbf{x})=\sum_{i=1}^{L} h_{i}(\mathbf{x}) w_{i}=h(\mathbf{x}) W
$$

Where:

$W=\left[w_{1}, w_{2} \ldots w_{L}\right]^{T}$ is the output weight matrix between the hidden the hidden neurons and output neurons; 
medRxiv preprint doi: https://doi.org/10.1101/2020.09.28.20203299; this version posted September 29, 2020. The copyright holder for this preprint (which was not certified by peer review) is the author/funder, who has granted medRxiv a license to display the preprint in It is made available under a CC-BY-NC-ND 4.0 International license .

$h(\mathbf{x})=\left[h_{1}, h_{2} \ldots h_{3}\right]$ is the hidden neuron outputs that represent the randomized hidden features of predictor $\boldsymbol{x}_{i}$;

$h_{i}(\mathbf{x})$ is the $i^{t h}$ hidden neuron.

The output function of the hidden neurons, $h_{i}(\mathbf{x})$ can be represented as follows [14]:

$$
h_{i}(\mathbf{x})=G\left(\mathbf{a}_{i}, b_{i}, \mathbf{x}\right), \quad \mathbf{a}_{i} \in R^{d}, b_{i} \in R
$$

$G\left(\mathbf{a}_{i}, b_{i}, \mathbf{x}\right)$, which is defined using hidden neuron parameters $(\mathbf{a}, b)$, is a non-linear piecewise continuous function that must satisfy the ELM approximation theorem [12-13-14].

To develop the proposed ELM model, the sigmoid transfer function was adopted, which has been widely adopted in neural network-based modelling, the sigmoid equation is expressed below:

$$
G(\mathbf{a}, b, \mathbf{x})=\frac{1}{1+e^{(-\mathbf{a} x+b)}}
$$

Huang et al.[14] state that the approximation error must be minimized when solving for the weights connecting the hidden and output layer $(W)$ using least square fitting:

$$
\min _{w \in R^{L \times m}}\|\mathbf{H} W-\mathbf{T}\|^{2}
$$

In Eq. (4), the term $\|\mathbf{H} W-\mathbf{T}\|$ is the Frobenius norm and $\mathbf{H}$ is the randomized hidden layer output matrix of the form [14]:

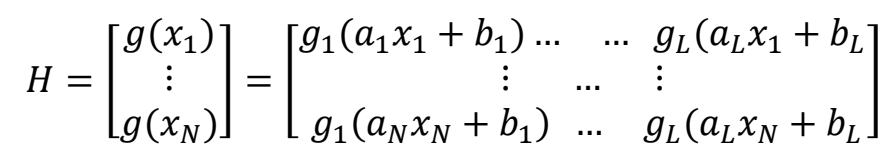

The target matrix in the data-training period is expressed in [14] as:

$$
\mathbf{T}=\left[\begin{array}{c}
\mathbf{t}_{1}^{T} \\
\vdots \\
\mathbf{t}_{N}^{T}
\end{array}\right]=\left[\begin{array}{ccc}
t_{11} & \cdots & t_{1 m} \\
\vdots & & \vdots \\
t_{N 1} & \cdots & t_{N m}
\end{array}\right]
$$

For these linear equations, an optimal solution was proposed in [12] as:

$$
W^{*}=\mathbf{H}^{+} \mathbf{T}
$$

where: $\mathbf{H}^{+}$: Moore-Penrose generalized inverse function $(+)$.

The optimal solution is then used in Eq. (7) to issue prediction for any given input vector $\mathbf{x}$.

\subsection{Model development}

A three-layered architecture was adopted for ELM model development (Fig. 2). The first layer (input layer) used the data (Table 2) as inputs. The output layer had one neuron representing the New COVID-19 Cases (NCC). For the single hidden layer, seven neurons a maximum were tested for each model. 
medRxiv preprint doi: https://doi.org/10.1101/2020.09.28.20203299; this version posted September 29, 2020. The copyright holder for this preprint (which was not certified by peer review) is the author/funder, who has granted medRxiv a license to display the preprint in It is made available under a CC-BY-NC-ND 4.0 International license .

Finding the appropriate number of nodes in the single layer hidden in the extreme learning machine neural network is a very difficult and critical task. A model with a large number of hidden nodes will have an excessive configuration, will follow the noise in the data and consequently will require more time in training phase, with the risk that overfitting occurs. The generalization properties during the test phase can be considerably influenced [13].

Some general rules for selecting the number of nodes in hidden layer (NNHL) are presented below:

1. Hecht-Nielsen [20] used the Kolmogorov theorem to prove that:

$$
N N H L \leq N_{\text {inputs }}+1
$$

2. Hecht-Nielsen [21] suggest that it should be:

$$
N_{\text {inputs }} \leq N N H L \leq 2 \times N_{\text {inputs }}+1
$$

3. Masters [22] suggests that the ANN architecture should resemble a pyramid with:

$$
N N H L=\sqrt{N_{\text {inputs }} \times N_{\text {output }}}
$$

Where:

$N_{\text {inputs }}$ and $N_{\text {output }}$ are respectively, the numbers of inputs and output.

For determining the optimum number of neurons in the hidden layer, initially, two neurons were tested. Subsequently, the number of neurons was gradually increased to 7 by an interval of one. Sigmoid activation function (sig) was adapted for all the ELM models tested in the hidden layer and linear function as transfer function (pure line) in the output layer.

\subsection{Criteria for evaluation}


medRxiv preprint doi: https://doi.org/10.1101/2020.09.28.20203299; this version posted September 29, 2020. The copyright holder for this preprint (which was not certified by peer review) is the author/funder, who has granted medRxiv a license to display the preprint in It is made available under a CC-BY-NC-ND 4.0 International license.

The best ELM configuration is adopted based on the minimum statistical error measurements (MSE, RMSE, MAE), the highest values of the performance parameters $\left(R^{2}, N S E, I O\right)$ between the calculated and predicted values using six statistical measures:

1. Mean-square error $(M S E)$;

2. Root-mean-square error (RMSE);

3. Mean Absolute Error (MAE)

4. Correlation Coefficient $(R)$;

5. Nash-Sutcliffe Coefficient of efficiency (NSE);

6. The overall index of model performance $(O I)$.

These parameters were calculated to check the performance of the developed models. These statistical performance evaluation criteria are expressed as follows:

$$
\begin{gathered}
M S E=\frac{1}{N} \sum_{i=1}^{N}\left(x_{p, i}-x_{o, i}\right)^{2} \\
R M S E=\sqrt{\frac{\sum_{i=1}^{N}\left(x_{p, i}-x_{o, i}\right)^{2}}{N}} \\
R=\frac{\sum_{i=1}^{N}\left[\left(x_{o, i}-\overline{x_{o}}\right) \times\left(\left(x_{p, i}-\overline{x_{p}}\right)\right)\right]}{\sqrt{\sum_{i=1}^{N}\left(x_{o, i}-\overline{x_{o}}\right)^{2} \times \sqrt{\sum_{=1}^{N}\left(x_{p, i}-\overline{x_{p}}\right)}}} \\
N S E=1.0-\frac{\sum_{i=1}^{N}\left(x_{o, i}-x_{p, i}\right)^{2}}{\sum_{i=1}^{N}\left(x_{o, i}-\overline{x_{o}}\right)^{2}} \\
O I=\frac{1}{2}\left(1-\left(\frac{R M S E}{x_{o, \max }-x_{o, \min }}\right)+\left(1-\frac{\sum_{i=1}^{N}\left(x_{p, i}-x_{o, i}\right)^{2}}{\sum_{i=1}^{N}\left(x_{o, i}-\overline{x_{o}}\right)^{2}}\right)\right)
\end{gathered}
$$

Where: $x_{o, i}=$ observed value; $x_{p, \mathrm{i}}=$ predicted value; $N=$ number of observations; $x_{o, \max }=$ maximum observed value; $x_{o, \min }=$ minimum observed value; and $\overline{x_{o}}=$ averaged observed 
medRxiv preprint doi: https://doi.org/10.1101/2020.09.28.20203299; this version posted September 29, 2020. The copyright holder for this preprint (which was not certified by peer review) is the author/funder, who has granted medRxiv a license to display the preprint in It is made available under a CC-BY-NC-ND 4.0 International license.

values; $\overline{x_{p}}=$ averaged predicted values.

Legates and McCabe [23] mentioned that RMSE has the advantage of expressing the error in the same units as the variable, so, providing more information about the efficiency of the model. A model with a lower RMSE value will have a high accuracy prediction. In addition a model with high value of $O I$ means a perfect fit between the observed and predicted data [24].

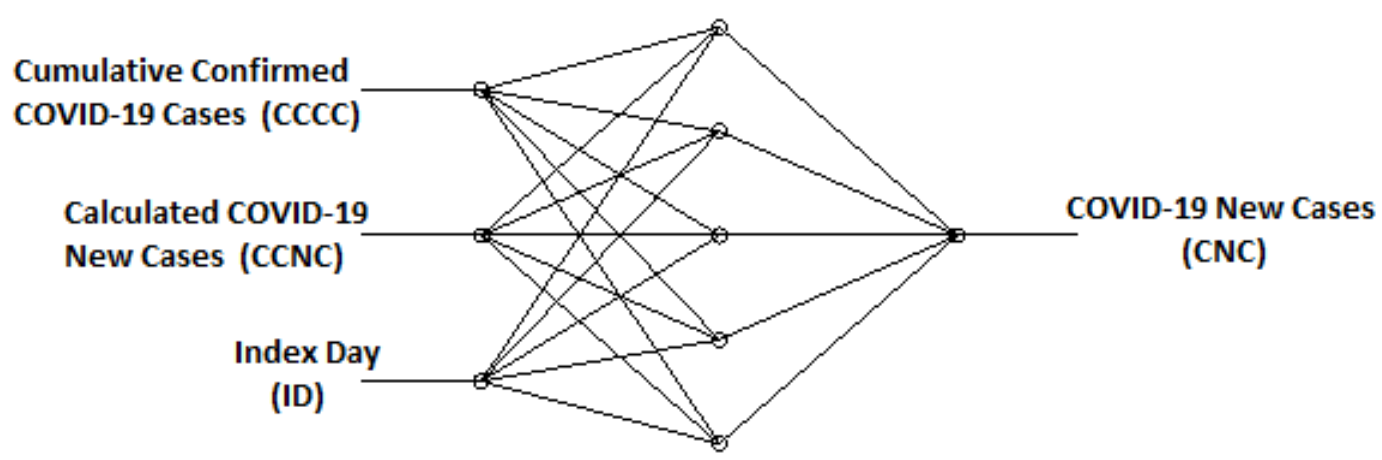

Figure 2. Architecture of the proposed ELM model (3-5-1).

\section{RESULTS AND DISCUSSION}

The ELM models development and construction process consists of the following five steps:

1) Selection of the input and the output data for training ELM model (data set).

2) Normalization of the input and the output data attributes.

3) Training of the normalized data using a hybrid-learning algorithm.

4) Testing the goodness of fit of the model.

5) Comparing the predicted output with the target output.

The input and the output data was normalized using min-max normalization; the data are normalized to values between 0 and 1 using the equation: 
medRxiv preprint doi: https://doi.org/10.1101/2020.09.28.20203299; this version posted September 29, 2020. The copyright holder for this preprint (which was not certified by peer review) is the author/funder, who has granted medRxiv a license to display the preprint in It is made available under a CC-BY-NC-ND 4.0 International license .

$$
X_{\text {nor }}=\frac{x_{i}-x_{\min }}{x_{\max }-x_{\min }}
$$

Where $x_{\min }$ and $x_{\max }$ are the minimum and maximum values of $x_{i}$, respectively.

After obtaining the normalized data, the next step is to train the input data using the proposed ELM model. ELM model uses Gradient-based Algorithms with Single Hidden Layer Network. The algorithm, by default, takes $80 \%$ of the input data for training. So out of 56 data, 45 data was randomly selected from the normalized dataset for training the model. The rest, 11 data, are kept for testing the model. After the testing is done, the ELM model is saved. Mean-squared error $(M S E)$, Root Mean-Squared Error (RMSE), and Mean Absolute Error (MAE) between calculated and predicted values are used as a performance index of the model accuracy, as it is shown in Table 2. 
medRxiv preprint doi: https://doi.org/10.1101/2020.09.28.20203299; this version posted September 29, 2020. The copyright holder for this preprint (which was not certified by peer review) is the author/funder, who has granted medRxiv a license to display the preprint in

It is made available under a CC-BY-NC-ND 4.0 International license .

Table 2: Performances parameters of ELM models with various number of neurons in hidden layer (the bold refers to the best model)

\begin{tabular}{|c|c|c|c|c|c|c|c|c|}
\hline ELM & $\boldsymbol{R}_{\text {TRAIN }}$ & $\boldsymbol{R}_{T E S T}$ & All $R$ & $M S E$ & RMSE & $M A E$ & $N S E$ & IO \\
\hline $3-2-1$ & 0.8481 & 0.7944 & 0.8876 & 511.91 & 22.6256 & 17.2148 & 0.7879 & 0.8329 \\
\hline $3-3-1$ & 0.9984 & 0.9988 & 0.9985 & 6.83 & 2.6145 & 1.9017 & 0.9971 & 0.9915 \\
\hline $3-4-1$ & 0.9999 & 0.9973 & 0.9998 & 0.80 & 0.8980 & 0.6117 & 0.9996 & 0.9974 \\
\hline $3-5-1$ & 0.9999 & 0.9998 & 0.9999 & 0.16 & 0.4114 & 0.2912 & 0.9999 & 0.9988 \\
\hline $3-6-1$ & 0.9999 & 0.9979 & 0.9998 & 0.66 & 0.8137 & 0.5102 & 0.9997 & 0.9979 \\
\hline $3-7-1$ & 0.9999 & 0.9991 & 0.9999 & 0.25 & 0.5002 & 0.2638 & 0.9998 & 0.9988 \\
\hline
\end{tabular}

The trials started using two neurons/nodes in the hidden layer as the initial start. As shown in the first row in Table 2, the values of MSE for CNC was 511.91.

The values of $R M S E$, respectively, for the first model (3-2-1), was 22.62. MAE values for CNC were 17.21 for the ELM model with two neurons in the hidden layer.

The value of $R$ in the training phase was estimated at 0.8481 , which shows a good similarity between the values of calculated and predicted $\mathrm{CNC}$ during the training process. For the testing phase, the value of $R$ was 0.7944 . The testing step reveals that the ELM model generalization ability is very satisfactory.

Increasing the neurons in the hidden layer gave a clear and marked improvement in the ELM model performance. Arriving at the topology 3-5-1, the lowest values of MSE are obtained, 0.16 for CNC. For this same topology, the lowest values of RMSE and MAE are obtained.

The highest value of $O I$ was respectively, 0.9988 is obtained with the ELM model 3-5-1. The analysis of the coefficient of efficiency (NSE) of the ELM models shows that the 3-5-1 model has the best value, namely 0.9999 .

It can be noted from the fig. 3 that predicted $\mathrm{CNC}$ values are quite close to the calculated $\mathrm{CNC}$ values, as their coefficient of determination $\left(R^{2}\right)$ value are very close to unity. 


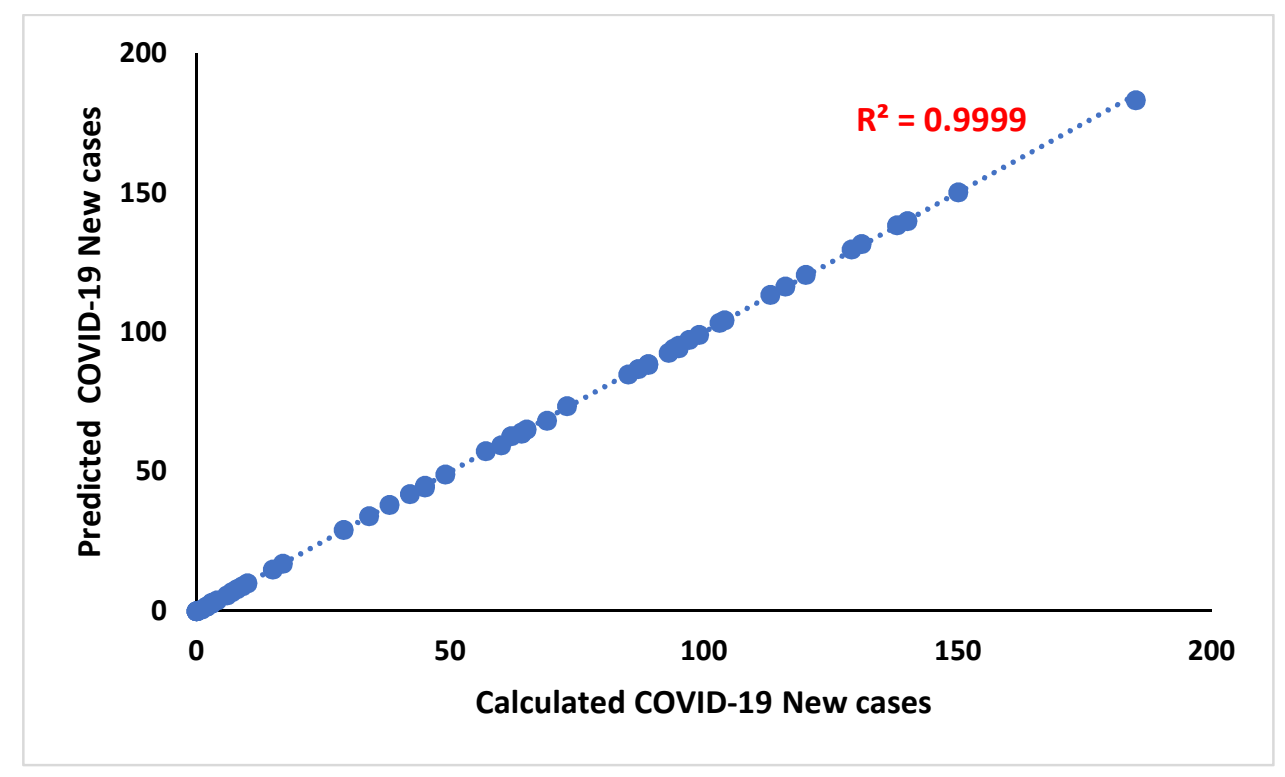

Fig. 3: Calculated COVID-19 new cases vs predicted new COVID-19 cases.

As a result, the most appropriate ELM architecture is 3-5-1 (bolded in Table 2), as this gave the best CNC prediction with the lowest error (MSE, RMSE, and MAE; and the maximum $R_{\text {all }}$ ). The best architecture of the developed ELM model is schematically illustrated in Fig. 2.

\section{CONCLUSION}

This paper proposed an extreme learning machine model (ELM) as machine learning technique for a prediction task. The proposed ELM model has a high ability to predict the number of new COVID-19 cases in Algeria with high accuracy, lowest errors (in terms of MSE, RMSE, and $M A E$ ), and highest performances parameters (NSE, IO, and $R^{2}$ ). According to the precise results obtained by the proposed ELM model, it can be used as a decision support tool to manage public health medical efforts and facilities against the COVID-19 pandemic crisis.

\section{REFERENCES}

1. Chen, Y.; Liu, Q.; Guo, D. Emerging coronaviruses: Genome structure, replication, and pathogenesis. J. Med. Virol. 2020.

2. Wang, L.F.; Shi, Z.; Zhang, S.; Field, H.; Daszak, P.; Eaton, B.T. Review of bats and SARS. Emerg. Infect. Dis. 2006, 12, 1834. 
medRxiv preprint doi: https://doi.org/10.1101/2020.09.28.20203299; this version posted September 29, 2020. The copyright holder for this preprint (which was not certified by peer review) is the author/funder, who has granted medRxiv a license to display the preprint in It is made available under a CC-BY-NC-ND 4.0 International license .

3. WHO Organization. Novel Coronavirus (2019-nCoV) 2020. Available online: https://www.who.int/ (accessed on 27 March 2020).

4. Cui, J.; Li, F.; Shi, Z.L. Origin and evolution of pathogenic coronaviruses. Nat. Rev. Microbiol. 2019, 17, 181-192.

5. Dehesh, T.; Mardani-Fard, H.A.; Dehesh, P. Forecasting of COVID-19 Confirmed Cases in Different Countries with ARIMA Models, medRxiv preprint doi: https://doi.org/10.1101/2020.03.13.20035345

6 Al-qaness; M.A.A.; Ewees, A.A.; Fan, H.; Abd El Aziz, M. Optimization Method for Forecasting Confirmed Cases of COVID-19 in China, J. Clin. Med. 2020, 9, 674; doi:10.3390/jcm9030674

7. Jung, S.M.; Akhmetzhanov, A.R.; Hayashi, K.; Linton, N.M.; Yang, Y.; Yuan, B.; Kobayashi, T.; Kinoshita, R.; Nishiura, H. Real-Time Estimation of the Risk of Death from Novel Coronavirus (COVID-19) Infection: Inference Using Exported Cases, J. Clin. Med. 2020, 9, 523; doi:10.3390/jcm9020523

8. Zhao, S.; Musa, S.S.; Lin, Q.; Ran, J.; Yang, G.; Wang, W.; Lou, Y.; Yang, L.; Gao, D.; He, D.; et al. Estimating the Unreported Number of Novel Coronavirus (2019-nCoV) Cases in China in the First Half of January 2020: A Data-Driven Modelling Analysis of the Early Outbreak. J. Clin. Med. 2020, 9, 388.

9. Nishiura, H.; Kobayashi, T.; Yang, Y.; Hayashi, K.; Miyama, T.; Kinoshita, R.; Linton, N.M.; Jung, S.m.; Yuan, B.; Suzuki, A.; et al. The Rate of Underascertainment of Novel Coronavirus (2019-nCoV) Infection: Estimation Using Japanese Passengers Data on Evacuation Flights. J. Clin. Med. 2020, 9, 419.

10. Tang, B.; Wang, X.; Li, Q.; Bragazzi, N.L.; Tang, S.; Xiao, Y.; Wu, J. Estimation of the Transmission Risk of the 2019-nCoV and Its Implication for Public Health Interventions. J. Clin. Med. 2020, 9, 462.]

11. Thompson, R.N. Novel Coronavirus Outbreak in Wuhan, China, 2020: Intense Surveillance Is Vital for Preventing Sustained Transmission in New Locations. J. Clin. Med. 2020, 9, 498

12. Huang G-B, Zhu Q-Y, Siew C-K. Extreme learning machine: theory and applications. Neurocomputing 2006; 70:489-501. 
medRxiv preprint doi: https://doi.org/10.1101/2020.09.28.20203299; this version posted September 29, 2020. The copyright holder for this preprint (which was not certified by peer review) is the author/funder, who has granted medRxiv a license to display the preprint in It is made available under a CC-BY-NC-ND 4.0 International license .

13. Huang, G-B.; Chen, L.; Siew, C-K. Universal approximation using incremental constructive feedforward networks with random hidden nodes. IEEE Trans Neural Netw 2006;17:879-92.

14. Huang, G.; Huang, G-B.; Song, S; You, K. Trends in extreme learning machines: a review. Neural Netw 2015; 61:32-48. https://doi.org/10.1016/j.neunet.2014.10.001

15. El Watan L'épidémie de coronavirus à Blida : Rues de plus en plus vides, hôpitaux dépassés.... [archive], El Watan, 18 March 2020 (access the website on April 20 2020)

16. Le Figaro_Coronavirus: 16 membr newspaperes d'une même famille contaminés en Algérie, [archive], on Le Figaro newspaper, 5 mars 2020 (access the website on April 20 2020)

17. El Watan_Épicentre de l'épidémie du Coronavirus, Blida se confine : «Le pire est à craindre..., [archive], on El Watan newspaper, 24 mars 2020 (access the website on April 20 2020)

18. https://fr.wikipedia.org/wiki/Pand $\% \mathrm{C} 3 \% \mathrm{~A} 9 \mathrm{mie}$ de_Covid-19 en_Alg\%C3\%A9rie

19 Yeom, C.-U.; Kwak, K.-C.; Yeom, C.-U.; Kwak, K.-C. Short-Term electricityload forecasting using a TSK-Based extreme learning machine with knowledge representation. Energies, 2017 10(10), 1613. https://doi.org/10.3390/en10101613.

20. Hecht-Nielsen, R. Kolmogorov's mapping neural network existence theorem, in Proceedings of the 1st IEEE International Joint Conference of Neural Networks, 1987, vol. 3, NY, USA, pp.: 11-14.

21. Hecht-Nielsen, R. Neurocomputing. Reading, Massachusetts: Addison-Wesley, 1990, MA, USA.

22. Masters, T. Practical Neural Network Recipes in C++, Academic Press Inc., 1993, CA, USA, 493 pages.

23. Lagates, D. R.; McCaby, Jr. G. J. Evaluating the use of "goodness-of-fit" measures in hydrologic and hydroclimatic model validation. Water Resources Research 199935 (1): 233-241.

24. Alazba, A.A.; Mattar, M.A.; El Nesr, M.N.; Amin, M.T. Field assessment of friction head loss and friction correction factor equations. Journal of Irrigation and Drainage Engineering 2012 138(2): 166-176. 
medRxiv preprint doi: https://doi.org/10.1101/2020.09.28.20203299; this version posted September 29, 2020. The copyright holder for this preprint (which was not certified by peer review) is the author/funder, who has granted medRxiv a license to display the preprint in It is made available under a CC-BY-NC-ND 4.0 International license . 


\title{
Predictive Modelling of COVID-19 New Cases in Algeria using An Extreme Learning Machines (ELM)
}

\author{
${ }^{1}$ Messaoud DJEDDOU ${ }^{2}$ Ibrahim A. HAMEED ${ }^{3}$ Abolfazl NEJATIAN ${ }^{4}$ Imed LOUKAM
}

1LARHYSS Laboratory, Faculty of Sciences and Technology, Mohamed Khider University, PO box 145 RP, 07000 Biskra, Algeria.

Email: djeddou.messaoud@gmail.com

2Department of ICT and Natural Sciences, Faculty of Information Technology and Electrical Engineering, Norwegian University of Science and Technology (NTNU), Postboks 1517, 6025 Ålesund, Norway

e-mail: $\underline{\text { ibib@ntnu.no }}$

3Department of Electrical Engineering, Florida Polytechnic University, FL, USA

Email: anejatian8607@floridapoly.edu

4INFRARES Laboratory Mohamed-Cherif Messaadia University-, Souk Ahras 41000, Algeria

email: i_loukam@hotmail.com

\begin{abstract}
:
In this research, an extreme Abstract: In this research, an extreme learning machine (ELM) is proposed to predict the new COVID- 19 cases in Algeria. In the present study, public health database from Algeria health ministry has been used to train and test the ELM models. The input parameters for the predictive models include Cumulative Confirmed COVID-19 Cases (CCCC), Calculated COVID-19 New Cases (CCNC), and Index Day (ID).

The predictive accuracy of the seven models has been assessed via several statistical parameters. The results showed that the proposed ELM model achieved an adequate level of prediction accuracy with smallest errors $(\mathrm{MSE}=0.16, \mathrm{RMSE}=0.4114$, and $\mathrm{MAE}=0.2912$ ), and highest performance's (NSE $\left.=0.9999, \mathrm{IO}=0.9988, \mathrm{R}^{2}=0.9999\right)$. Hence, the ELM model could be utilized as a reliable and accurate modelling approach for predicting the new COVIS-19 cases in Algeria.
\end{abstract}




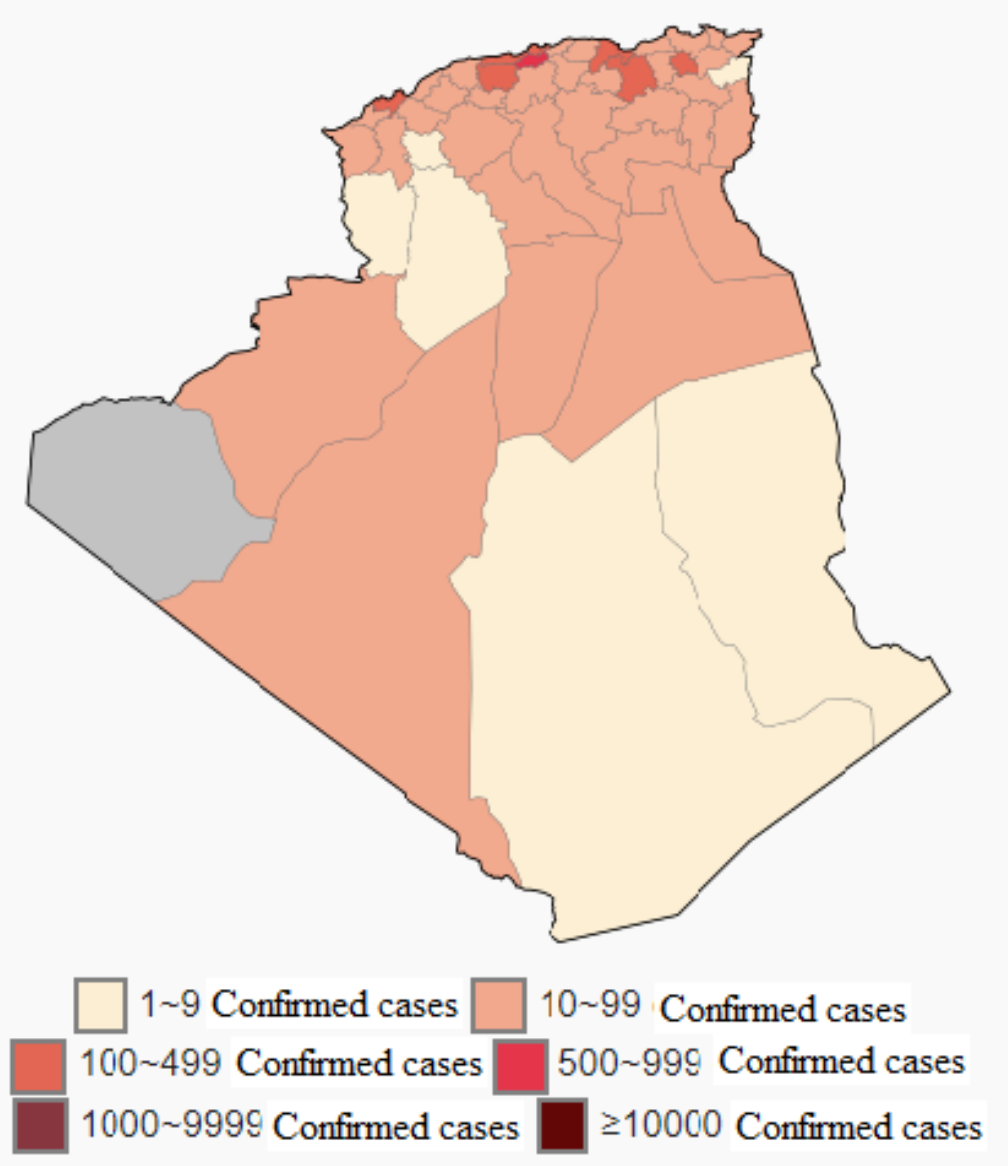

Figure 1: Map of the Covid-19 pandemic in Algeria [24]

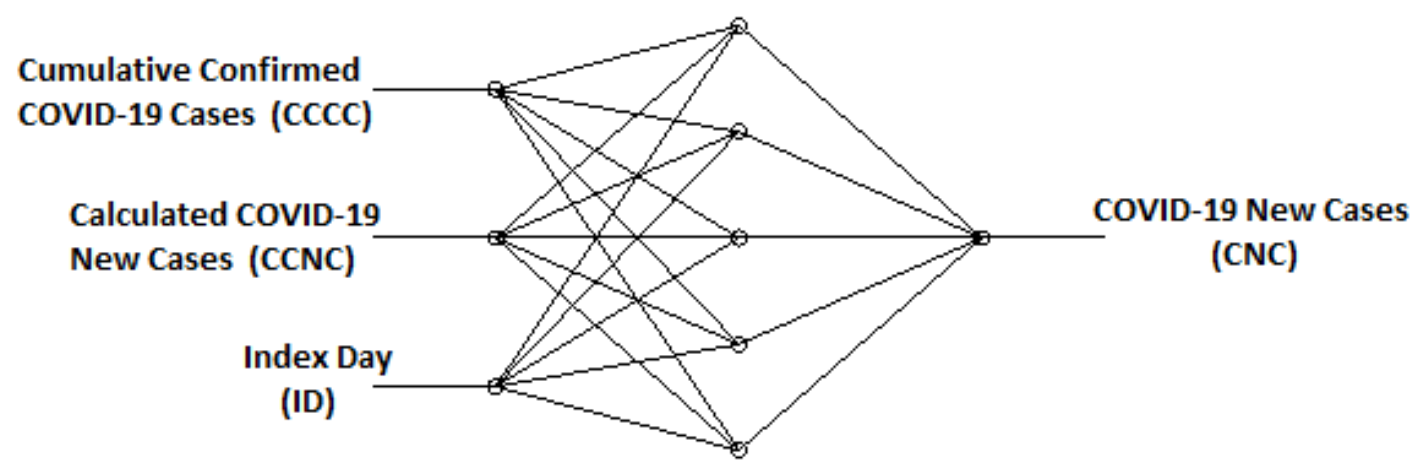

Figure 2. Architecture of ELM model proposed in the study. 


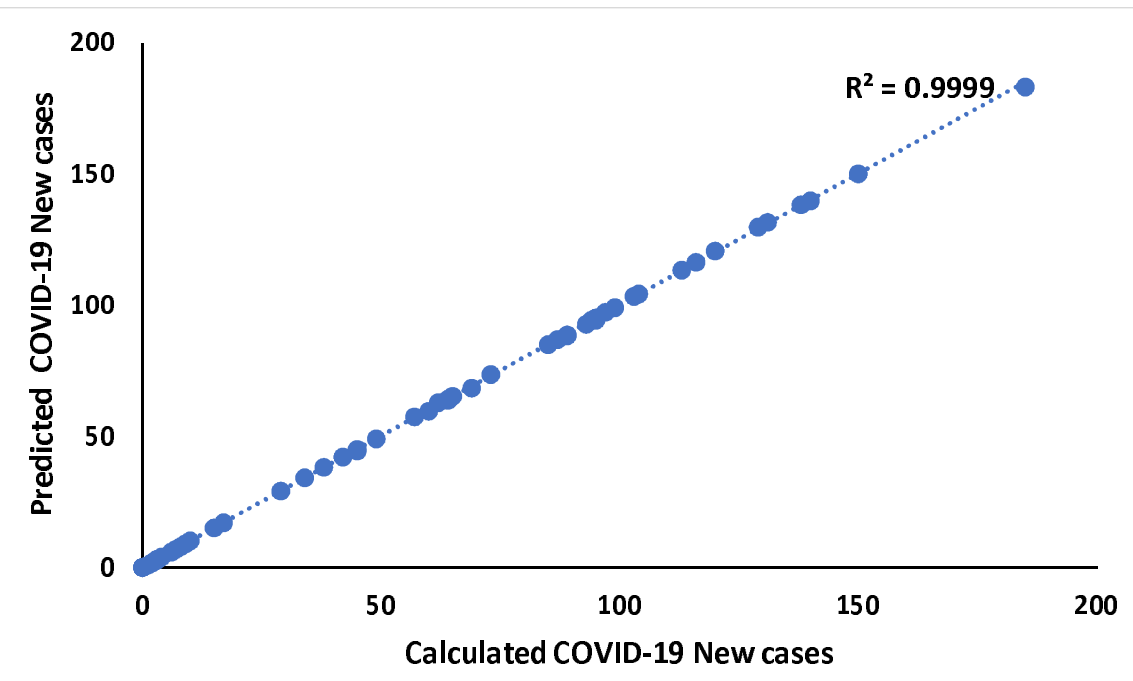

Figure. 3: The comparison of the calculated A values with the predicted A values from the ELM model (3-5-1). 